Article

\title{
Korean Maritime Cadets' Onboard Training Environment Survey
}

\author{
Jinwoo Lee ${ }^{1} \mathbb{C}$, Surindar Dhesi ${ }^{2}$, Ian Phillips ${ }^{2}$, Moonsoo Jeong ${ }^{3}$ and Changhee Lee ${ }^{3, *(\mathbb{D}}$ \\ 1 Ocean Technology Training Team, Korea Institute of Maritime and Fisheries Technology, Busan 48562, Korea; \\ ejw@seaman.or.kr \\ 2 School of Geography, Earth and Environmental Sciences, University of Birmingham, \\ Birmingham B15 2TT, UK; s.k.dhesi@bham.ac.uk (S.D.); i.d.phillips@bham.ac.uk (I.P.) \\ 3 Division of navigation convergence, Korea Maritime and Ocean University, Busan 49112, Korea; \\ jms@kmou.ac.kr \\ * Correspondence: chlee@kmou.ac.kr; Tel.: +82-010-8577-8618 or +82-051-410-4642; Fax: +82-051-404-3985
}

Citation: Lee, J.; Dhesi, S.; Phillips, I.; Jeong, M.; Lee, C. Korean Maritime Cadets' Onboard Training Environment Survey. Sustainability 2021, 13, 4161. https://doi.org/ $10.3390 /$ su13084161

Academic Editor: Arijit De

Received: 5 March 2021

Accepted: 5 April 2021

Published: 8 April 2021

Publisher's Note: MDPI stays neutral with regard to jurisdictional claims in published maps and institutional affiliations.

Copyright: (c) 2021 by the authors. Licensee MDPI, Basel, Switzerland. This article is an open access article distributed under the terms and conditions of the Creative Commons Attribution (CC BY) license (https:// creativecommons.org/licenses/by/ $4.0 /)$.
Abstract: The onboard training environment is important for the continuity of cadets' maritime careers and for the wider industry. Various studies have been conducted with the aim of improving the onboard training environment of cadets in various respects including education, health and safety, and sexual harassment. However, there is a lack of research that details the problems associated with onboard training and how the safety of cadets is managed in the field. Descriptive and nonparametric statistics were used to analyze the data from 284 cadets from maritime universities and 41 shipping company employees in South Korea collected between March and July 2020. The results show that many cadets are not guaranteed enough rest time and the provision of personal protective equipment. In addition, some companies consider cadets to be crew members or temporary workers. To improve the training environment, recommendations include the evaluation of the ship's environment to establish whether it is suitable for training, constant monitoring of whether the onboard training guidelines are maintained in the field, strengthening of preventive education on human rights violations, and expanding efforts continuously not only to physically improve the onboard training environment but systematically manage cadets as students.

Keywords: maritime trade; cadets; onboard training

\section{Introduction}

Maritime transport accounts for more than four-fifths of the world's merchandise trade by volume [1], and seafarers play an important role in maritime trade. Working at sea is hazardous and has a higher fatal accident rate than other industries [2], e.g., the construction industry and manufacturing. For the safe operation of ships, the qualification and competence of seafarers is important, and vocational education and training (VET) helps to prepare individuals by continuously developing their knowledge and skills [3].

The International Maritime Organization (IMO) established the International Convention on Standards of Training, Certification, and Watchkeeping for Seafarers (STCW) in 1978 to set mandatory minimum requirements for the certification of seafarers [4]. As per Chapter II (Standards regarding the Master and Deck Department) and Chapter III (Standards regarding the Engine Department) of the STCW, cadets should complete onboard training to achieve a certificate of competency [5,6].

Onboard training is meaningful because it provides opportunities for cadets to practice the knowledge they have learned during their education [7,8]. However, there are some problems associated with onboard training. For example, in some cases, cadets experienced sexual harassment during onboard training [9]. There are also issues related to group life in a restricted area and restrictions on individual basic rights [8]. 
Seafarers are important in the South Korean shipping industry, as most international merchandise trade takes place by sea [10]. However, the number of Korean seafarers continuously decreases [11] as negative perceptions influence job aspirations [12].

The onboard training environment is important for the continuity of maritime careers and the wider industry. Accidents during onboard training, which can create a negative perception of seafarers, have occurred recently [13].

Various studies have been conducted regarding the improvement of onboard training environments. In terms of the effectiveness of onboard training, an effective training program can be formulated if onboard training is taken seriously [14] and a realistic curriculum is created that includes legal inspections of ships during the semester and practicing the use of various types of equipment [4]. Sin and Im [15] examined differences in cadets' satisfaction with their onboard training on shipping companies' ships and universities' training ships in the categories of consciousness, education, and environment, and found that shipping companies need to offer more systematic education to cadets and that universities need to improve education environments by paying attention to living environments and food quality.

With regard to training conditions, Zhao et al. [9] argued that female Chinese cadets face discrimination regarding the opportunity to sail and develop their careers at sea, and sexual harassment could be an issue for them. Those with less power are more likely to experience sexual harassment and bullying on board a ship [16,17]. Yildiz et al. [7] reviewed deck cadets' onboard training conditions and concluded that it is necessary to improve social opportunities and working conditions to ensure safe onboard operations and the occupational continuity of deck cadets.

The mental health and well-being of seafarers is a growing concern. Mental health and well-being can be affected by various factors, including long periods of time at sea, isolation, loneliness, cross-cultural conflict, and poor food quality $[18,19]$. For cadets, their assignments, personal psychological factors, and the crew's attitude can also be highlevel stressors [5]. It is difficult to define the most significant contributing factor for the improvement of mental health and well-being on board because there are considerable variations in mental health between people [18]. However, improving the conditions of life onboard, including the provision of internet access, facilities for recreational activities, and furnishings within cabins could help to improve the mental health and wellbeing of those onboard [19].

Various studies have been conducted regarding the improvement of the onboard training environment of cadets in various respects such as education, health and safety, and sexual harassment. However, there is a lack of research that details the problems associated with onboard training and how the safety of cadets is actually managed in the field.

This article attempts to identify details regarding the actual training environments of cadets during onboard training, including working hours, living conditions, support provided during the training, and the company's views about onboard training and cadets. The main findings will contribute to a determination of the specific problems associated with Korean maritime cadets' onboard training, in which areas prompt action is required, and how best to respond effectively to the problems that are identified.

\section{Materials and Methods}

Our research targeted Korean maritime cadets who completed onboard training as required by the STCW Convention and attended maritime universities in South Korea, as well as employees of shipping companies that provided onboard training opportunities to maritime university students in South Korea.

The survey was conducted using the Google online survey platform and email between March and July 2020. Students and shipping company employees participated in the survey voluntarily and anonymously. The data collected were strictly managed in accordance with Article 33 (Protection of Secrets) of the Statistics Act in South Korea, the contents of which were explained to survey participants in advance. Of the 500 maritime 
university students who were randomly selected and asked to participate in the survey, 289 students participated, and five were excluded from the analysis because they had no onboard training experience. Of the 100 shipping company employees who were asked to participate in the survey, 41 participated.

Based on the previous literature $[7,15,16]$, a new instrument to identify more detailed information relevant to the onboard training environment was built. The questionnaire for cadets covers details regarding the onboard environment where cadets completed their training, problems experienced during onboard training, and their expectations for the training environment. In the questionnaire for those in charge of onboard training at shipping companies, the researchers focused on the company's views regarding onboard training and cadets.

The survey was analyzed using IBM SPSS version 25 to identify areas in the onboard training environment that need improvement. Descriptive and non-parametric statistical analyses were used in the data analysis to describe the detailed onboard training environment and the association between gender and sexual harassment.

\section{Results}

\subsection{Korean Maritime Cadets}

\subsubsection{Descriptive Statistics}

A total of 284 Korean maritime cadets participated in the survey. As can be seen from Table 1, where their details are described, most of the cadets were male, belonged to the navigation department, and participated in training for more than three and less than seven months.

Table 1. Cadets who participated in the survey.

\begin{tabular}{|c|c|c|c|c|c|}
\hline Gender & $n(\%)$ & Department & $n(\%)$ & Period of First Apprenticeship & $n(\%)$ \\
\hline Male & $\begin{array}{c}228 \\
(80.3)\end{array}$ & Navigation & $\begin{array}{c}200 \\
(70.4)\end{array}$ & Less than 1 month & $\begin{array}{c}22 \\
(7.7)\end{array}$ \\
\hline Female & $\begin{array}{c}38 \\
(13.4)\end{array}$ & Engine & $\begin{array}{c}84 \\
(29.6)\end{array}$ & $\begin{array}{l}\text { More than } 1 \text { month and less than } \\
3 \text { months }\end{array}$ & $\begin{array}{c}25 \\
(8.8)\end{array}$ \\
\hline \multirow[t]{6}{*}{$\begin{array}{l}\text { Prefer not } \\
\text { to say }\end{array}$} & $\begin{array}{l}18 \\
(6.3)\end{array}$ & & & $\begin{array}{l}\text { More than } 3 \text { months and less than } \\
5 \text { months }\end{array}$ & $\begin{array}{c}59 \\
(20.8)\end{array}$ \\
\hline & & & & More than 5 months and less than & 165 \\
\hline & & & & 7 months & $(58.1)$ \\
\hline & & & & $\begin{array}{l}\text { More than } 7 \text { months and less than } \\
9 \text { months }\end{array}$ & 6 \\
\hline & & & & More than 9 months and less than & 7 \\
\hline & & & & 12 months & (2.5) \\
\hline
\end{tabular}

Table 2 describes the characteristics of the vessels on which the Korean maritime cadets were trained. Most of the cadets participated in onboard training on various types of ships with a gross tonnage of more than 3000 and with multinational crews.

\subsubsection{Onboard Training Environment}

With regard to orientation training, the number of cadets who did and did not receive orientation training before the onboard training accounted for $242(85.2 \%)$ and $42(14.8 \%)$ cadets, respectively. Regarding cabins, $272(95.8 \%)$ cadets were provided with private cabins and $12(4.2 \%)$ were not. In the case of the 12 cadets who were not provided with private cabins, the number of cadets who answered that they shared a room with three people, two people, four people, six people, or any other number, account for five (41.7\%), three $(25.0 \%)$, two $(16.7 \%)$, one $(8.3 \%)$ and one $(8.3 \%)$ in order of frequency, respectively. In the case of private rooms, most were equipped with learning spaces and living facilities such as desks, showers, and toilets, but in the case of shared rooms, only a small number of cabins were equipped with learning spaces and living facilities (Table 3). 
Table 2. Characteristics of vessels on which Korean maritime cadets were trained $(n=284)$.

\begin{tabular}{|c|c|c|c|c|c|}
\hline Vessel Type & $n(\%)$ & $\begin{array}{c}\text { Gross } \\
\text { Tonnage }\end{array}$ & $n(\%)$ & $\begin{array}{c}\text { Crew's } \\
\text { Nationality }\end{array}$ & $\begin{array}{c}n \\
(\%)\end{array}$ \\
\hline Bulk carrier & $\begin{array}{c}39 \\
(13.7)\end{array}$ & Under 2999 & $4(1.4)$ & $\begin{array}{l}\text { All Korean } \\
\text { seafarers }\end{array}$ & $\begin{array}{c}83 \\
(29.2)\end{array}$ \\
\hline Chemical carrier & $\begin{array}{l}28 \\
(9.9)\end{array}$ & 3000-9999 & $42(14.8)$ & $\begin{array}{c}\text { All foreign } \\
\text { seafarers }\end{array}$ & $\begin{array}{c}3 \\
(1.1)\end{array}$ \\
\hline LNG/LPG carrier & $63(22.2)$ & $10,000-29,999$ & $55(19.4)$ & $\begin{array}{c}\text { Mixed } \\
\text { (Korean officers } \\
\text { and foreign crew) }\end{array}$ & $\begin{array}{c}173 \\
(60.9)\end{array}$ \\
\hline Car carrier & $\begin{array}{c}40 \\
(14.1)\end{array}$ & $30,000-49,999$ & $45(15.8)$ & $\begin{array}{c}\text { Mixed } \\
\text { (multinational } \\
\text { officers and } \\
\text { multinational } \\
\text { crew) }\end{array}$ & $\begin{array}{c}24 \\
(8.5)\end{array}$ \\
\hline Container ship & $\begin{array}{c}44 \\
(15.5)\end{array}$ & $50,000-99,999$ & $\begin{array}{c}74 \\
(26.1)\end{array}$ & $\begin{array}{c}\text { Other(prefer not to } \\
\text { say) }\end{array}$ & $\begin{array}{c}1 \\
(0.4)\end{array}$ \\
\hline Passenger ship & $\begin{array}{c}3 \\
(1.1)\end{array}$ & Over 100,000 & $\begin{array}{c}64 \\
(22.5)\end{array}$ & & \\
\hline $\begin{array}{c}\text { Training ship } \\
\text { (university/institute) }\end{array}$ & $\begin{array}{c}46 \\
(16.2)\end{array}$ & & & & \\
\hline $\begin{array}{c}\text { Other } \\
\text { (oil tanker, prefer not } \\
\text { to say) }\end{array}$ & $\begin{array}{l}21 \\
(7.4)\end{array}$ & & & & \\
\hline
\end{tabular}

Table 3. Amenities provided in cadet's cabins.

\begin{tabular}{|c|c|c|c|c|}
\hline & \multicolumn{2}{|c|}{ Private Cabin $(n=272)$} & \multicolumn{2}{|c|}{ Shared Cabin $(n=12)$} \\
\hline & Yes & No & Yes & No \\
\hline Refrigerator & $210(77.2 \%)$ & $62(22.8 \%)$ & $3(25.0 \%)$ & $9(75.0)$ \\
\hline TV & $46(16.9 \%)$ & $226(83.1 \%)$ & $2(16.7 \%)$ & $10(83.3 \%)$ \\
\hline Internet & $186(68.4 \%)$ & $86(31.6 \%)$ & $5(41.7 \%)$ & $7(58.3 \%$ \\
\hline Shower & $254(93.4 \%)$ & $18(6.6 \%)$ & $4(33.3 \%)$ & $8(66.7 \%)$ \\
\hline Toilet & $256(94.1 \%)$ & $16(5.9 \%)$ & $4(33.3 \%)$ & $8(66.7 \%)$ \\
\hline Desk and chair & $268(98.5 \%)$ & $4(1.5 \%)$ & $8(66.7 \%)$ & $4(33.3 \%)$ \\
\hline Table and sofa & $240(88.2 \%)$ & $32(11.8 \%)$ & $5(41.7 \%)$ & $7(58.3 \%)$ \\
\hline
\end{tabular}

Concerning personal protective equipment (PPE), most cadets were given a head protector, hand protectors, and foot protectors, but the provision rate of other types of equipment such as boiler suits, eye protectors, and ear protectors was relatively low (Figure 1).

With some exceptions, according to Article 60 (Working Hours and Time to Rest) and Article 61 (Working Hours of Minor Seafarers) of the Seafarers Act in South Korea, working hours should not exceed $8 \mathrm{~h}$ a day and $40 \mathrm{~h}$ a week. In terms of the average working hours per day, however, only $60(21.1 \%)$ of the cadets answered that they worked less than $8 \mathrm{~h}$ a day, and the rest worked more than $8 \mathrm{~h}$ a day. Specifically, $156(54.9 \%), 51(18.0 \%)$, $10(3.5 \%), 2(7 \%)$, and $5(1.8 \%)$ cadets worked $9-12$ h, 13-16 h, 17-20 h, 21-24 h, or irregular hours, respectively. Regarding working hour registers, 186 (65.5\%) cadets had a register, but $98(34.5 \%)$ did not. Of the 186 cadets who had a register, only $80(43.0 \%)$ thought that their working hours were accurately recorded.

In connection with requests to perform uncomfortable tasks, $117(41.2 \%)$ out of 284 cadets were asked to perform a task that they were uncomfortable with during their onboard training. Among the five examples presented, the uncomfortable tasks chosen by the cadets were office assistant work ( $n=32,27.4 \%)$, attending a company get-together ( $n=25,21.4 \%)$, additional maintenance work outside of working hours $(n=24,20.5 \%)$, additional watchkeeping outside of working hours $(n=14,12.0 \%)$, and other tasks including private errands such as massages and cooking $(n=22,18.8 \%)$. Referring to their reaction to the request to perform an uncomfortable task, of the 117 cadets who had received such a request, 95 responded, and the form of response was following instructions ( $n=63,66.3 \%)$, complaining directly to the person who requested performance of the task $(n=15,15.8 \%)$, 
asking the senior officers on the vessel for help $(n=9,9.5 \%)$, reporting to the company $(n=5,5.3 \%)$, and reporting to the university $(n=3,3.2 \%)$.

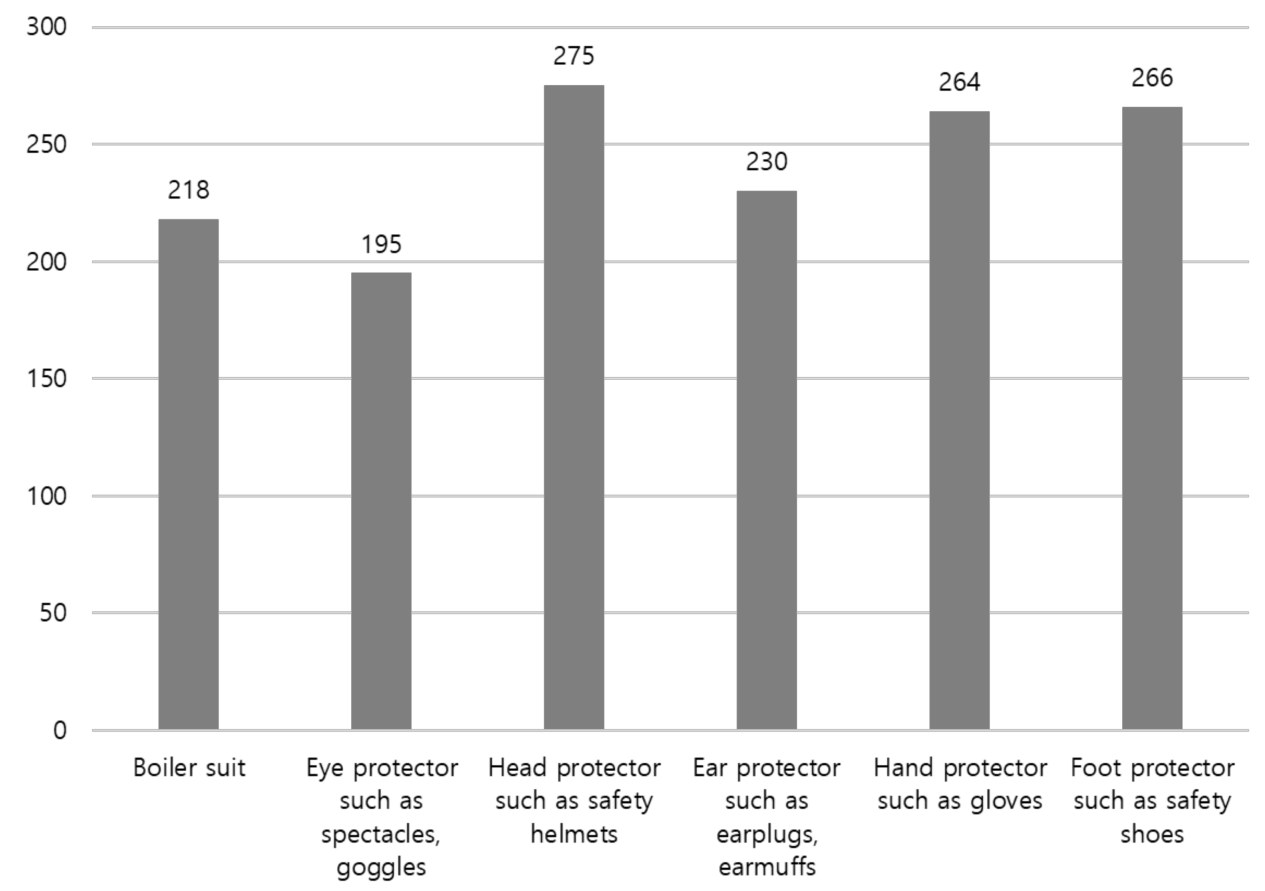

Figure 1. Personal protective equipment provision status $(n=284)$.

Table 4 shows the association between gender and sexual harassment experience. Of the 284 cadets, 38 (13.4\%) experienced sexual harassment during their onboard training. Specifically, 21 out of 228 male cadets experienced sexual harassment, and 11 out of 38 female cadets experienced sexual harassment. Thus, there was a statistically significant association $\left(\chi^{2}=17.549, \mathrm{df}=2, p<0.001\right)$ between gender and sexual harassment.

Table 4. Association between gender and experience of sexual harassment.

\begin{tabular}{ccccc}
\hline & \multicolumn{3}{c}{ Experience of Sexual Harassment } \\
\cline { 2 - 4 } & & Yes & No & Total \\
\cline { 2 - 4 } & Male & $21(9.2)$ & $207(90.8)$ & 228 \\
Gender & Female & $11(28.9)$ & $27(71.1)$ & 38 \\
(Percentage within each group) & Prefer not to say & $6(33.3)$ & $12(66.7)$ & 18 \\
Total & & 38 & 246 & 284 \\
\hline
\end{tabular}

Details regarding sexual harassment are presented in Table 5. A definition of sexual harassment as defined by Article 3 of the Framework Act on Gender Equality in South Korea was provided to the cadets. Sexual harassment involves making the other person feel humiliated by verbal and physical behavior in connection with his/her position or duties. Most of the cadets who experienced sexual harassment were harassed twice or more $(n=27,71.1 \%)$. The majority of sexual harassment occurred on the bridge $(n=18,47.4 \%)$, in the engine room $(n=7,18.4 \%)$, and in individual cabins $(n=7,18.4 \%)$. Sexual harassment against cadets was mainly perpetrated by officers such as captains/chief engineers $(n=14$, $36.8 \%)$, first mates/engineers $(n=10,26.3)$, and second/third mates/engineers $(n=6$, $15.8 \%$ ). Referring to their reactions, of the 38 cadets who experienced sexual harassment during their onboard training, the forms of response were "I only talked to my close friends" $(n=18,47.4 \%)$, "I just put up with it" ( $n=11,28.9 \%)$, "I notified the company" $(n=3,7.9 \%)$, and other reactions $(n=6,15.8 \%)$, including "I was angry with him" $(n=2)$, 
"I did not realize it was sexual harassment" $(n=1)$, "I just stared at him until he stopped it" $(n=1)$, "I paid him back with bad words $(n=1)$, and "I reported it to the captain" $(n=1)$.

Table 5. Reports of sexual harassment $(n=38)$.

\begin{tabular}{cccccc}
\hline Frequency & $\boldsymbol{n} \mathbf{( \% )}$ & Place & $\boldsymbol{n ( \% )}$ & Perpetrator & $\boldsymbol{n}(\mathbf{\%})$ \\
\hline 1 time & $11(28.9)$ & Bridge & $18(47.4)$ & $\begin{array}{c}\text { Captain/chief } \\
\text { engineer }\end{array}$ & $14(36.8)$ \\
$2-3$ times & $10(26.3)$ & Engine room & $7(18.4)$ & $\begin{array}{c}\text { First } \\
\text { mate/engineer } \\
\text { Second /third }\end{array}$ & $10(26.3)$ \\
$4-9$ times & $9(23.7)$ & Dining area & $2(5.3)$ & mate/engineer & $6(15.8)$ \\
10 times or more & $8(21.1)$ & Individual cabin & $7(18.4)$ & Crew & $3(7.9)$ \\
& & Other & $4(10.5)$ & Other & $5(13.2)$ \\
\hline
\end{tabular}

\subsubsection{Cadet's Views on the Onboard Training Environment}

Table 6 shows the problems and positive aspects of onboard training presented for cadets to choose from, as well as the status of the cadets' responses. There was a similar percentage of responses to various problems with onboard training, but there were relatively high responses regarding unreasonable onboard working systems, isolation from social life, and relationships with superiors. Although it was a minority opinion, frequent drinking parties, COVID-19, and low onboard training monetary allowances were also suggested as problems with onboard training.

Table 6. Problems with and positive aspects of onboard training $(n=284)$.

\begin{tabular}{|c|c|c|c|}
\hline Problems with Onboard Training & $n(\%)$ & $\begin{array}{l}\text { Positive Aspects of } \\
\text { Onboard Training }\end{array}$ & $n(\%)$ \\
\hline $\begin{array}{c}\text { Unreasonable working hours } \\
\text { and conditions }\end{array}$ & 48 (16.9) & $\begin{array}{l}\text { Practicing the knowledge learned } \\
\text { at university }\end{array}$ & $117(41.2)$ \\
\hline $\begin{array}{l}\text { Being isolated from social and } \\
\text { family life }\end{array}$ & 47 (16.5) & $\begin{array}{l}\text { Experiencing the working culture } \\
\text { on a ship }\end{array}$ & $94(33.1)$ \\
\hline Unhelpful attitudes of superiors & $44(15.5)$ & Visiting various countries & $19(6.7)$ \\
\hline $\begin{array}{l}\text { Unsystematic onboard training } \\
\text { (poor education, insufficient } \\
\text { training and experience) }\end{array}$ & $43(15.1)$ & $\begin{array}{l}\text { Cultivating sociality by working } \\
\text { with various people }\end{array}$ & $18(6.3)$ \\
\hline Homesickness & $25(8.8)$ & $\begin{array}{l}\text { Improving cultural understanding } \\
\text { through work with foreign } \\
\text { seafarers }\end{array}$ & $14(4.9)$ \\
\hline Long training period & $22(7.7)$ & Promoting pride in being seafarers & $11(3.9)$ \\
\hline $\begin{array}{l}\text { Being unauthorized for a } \\
\text { given task }\end{array}$ & $18(6.3)$ & Other & $11(3.9)$ \\
\hline Dangerous and difficult tasks & $11(3.9)$ & & \\
\hline Other & $26(9.2)$ & & \\
\hline
\end{tabular}

With respect to the positive aspects of onboard training, practicing the knowledge that was learned at university and experiencing the working culture on a ship accounted for the majority, while other opinions such as visiting various countries, cultivating sociality by working with various people, improving cultural understanding through work with foreign seafarers, and promoting pride in being seafarers were relatively small. Other aspects included improving their patience in difficult situations and learning various things.

Table 7 shows the suggestions of Korean cadets for improving their welfare and rights during their onboard training. Sufficient rest time, communication with the outside, and systematic onboard training programs could be listed as the most necessary interventions for the expansion of the welfare of cadets during their onboard training. In addition, improving the legal system relating to cadets, strengthening the supervision of ship companies at the government level, and expanding cadet rights protection education were the most necessary interventions for the protection of the rights of the cadets during their training. 
Table 7. Korean cadets' suggestions for improving their welfare and rights during onboard training $(n=284)$.

\begin{tabular}{|c|c|c|c|}
\hline Welfare & $n(\%)$ & Rights & $n(\%)$ \\
\hline Sufficient rest time & $133(46.8)$ & $\begin{array}{l}\text { Improving the legal system } \\
\text { relating to cadets }\end{array}$ & $102(35.9)$ \\
\hline $\begin{array}{l}\text { Communication with the outside } \\
\text { (Internet, SNS, etc.) }\end{array}$ & $39(13.7)$ & $\begin{array}{l}\text { Strengthening the supervision of } \\
\text { the ship company at the } \\
\text { government level }\end{array}$ & $52(18.3)$ \\
\hline $\begin{array}{l}\text { Systematic onboard } \\
\text { training program }\end{array}$ & $38(13.4)$ & $\begin{array}{l}\text { Expansion of cadet rights } \\
\text { protection education }\end{array}$ & $46(16.2)$ \\
\hline $\begin{array}{l}\text { Rational onboard training } \\
\text { monetary allowance }\end{array}$ & $23(8.1)$ & $\begin{array}{l}\text { Reinforcement of corporate social } \\
\text { responsibility and ethics } \\
\text { management system }\end{array}$ & $30(10.6)$ \\
\hline Better food & $19(6.7)$ & Introduction of a mentoring system & $29(10.2)$ \\
\hline Individual cabin & $11(3.9)$ & $\begin{array}{l}\text { Expending training on } \\
\text { university/institute training ships }\end{array}$ & $19(6.7)$ \\
\hline $\begin{array}{l}\text { Recreational facilities (games, } \\
\text { sports, etc.) }\end{array}$ & $4(1.4)$ & Other & $6(2.1)$ \\
\hline Other & $17(6)$ & & \\
\hline
\end{tabular}

The researchers asked the Korean cadets if their onboard training strengthened their will to board a ship. While the majority of the cadets $(n=223,78.5 \%)$ answered in the affirmative, a significant number $(n=61,21.5 \%)$ answered in the negative. The answers were not statistically different between male and female cadets $\left(\chi^{2}=1.663, \mathrm{df}=1, p=0.197\right)$. Regarding the effect of their onboard training on their thoughts about becoming a seafarer, Korean cadets indicated that the training had either a very negative effect $(n=10,3.5 \%)$, a negative effect $(n=25,8.8 \%)$, a neutral effect $(n=95,33.5 \%)$, a positive effect $(n=93,32.7 \%)$, or a very positive effect $(n=61$, $21.5 \%$ ). The Mann-Whitney U test showed that there was no statistically significant difference between male and female cadets $(\mathrm{U}=4920.5, p=0.161)$.

\subsection{Shipping Companies}

\subsubsection{Descriptive Statistics}

The survey was conducted by targeting those in charge of onboard training at shipping companies that provide such training to maritime university students in South Korea. Table 8 shows the details of the company employees that participated in the survey.

Table 8. Shipping company employees participating in the survey.

\begin{tabular}{|c|c|c|}
\hline & Specification & $n(\%)$ \\
\hline \multirow{3}{*}{ Gender } & Male & $40(97.6)$ \\
\hline & Female & - \\
\hline & Prefer not to say & $1(2.4)$ \\
\hline \multirow{4}{*}{ Age } & $20 \sim 29$ & $5(12.2)$ \\
\hline & $30 \sim 39$ & $16(39.0)$ \\
\hline & $40 \sim 49$ & $18(43.9)$ \\
\hline & $50 \sim 59$ & $2(4.9)$ \\
\hline \multirow{5}{*}{ Department } & Navigation & $15(36.6)$ \\
\hline & Engine & $12(29.3)$ \\
\hline & Human resources & $9(22.0)$ \\
\hline & Marketing & $3(7.3)$ \\
\hline & Other & $2(4.9)$ \\
\hline \multirow{5}{*}{ Work experience in the maritime industry } & Less than 5 years & $3(7.3)$ \\
\hline & More than 5 years, less than 10 years & $10(24.4)$ \\
\hline & More than 10 years, less than 15 years & $10(24.4)$ \\
\hline & More than 15 years, less than 20 years & $15(36.6)$ \\
\hline & More than 20 years & $3(7.3)$ \\
\hline \multirow{6}{*}{ Size of the company's fleet } & Less than 30 & $12(29.3)$ \\
\hline & $30 \sim 49$ & $10(24.4)$ \\
\hline & $50 \sim 69$ & 8 (19.5) \\
\hline & 70 99 & 8 (19.5) \\
\hline & More than 100 & $1(2.4)$ \\
\hline & Do not know & $2(4.9)$ \\
\hline
\end{tabular}




\subsubsection{Company's Views on Cadets and Onboard Training}

Referring to the company's policy on trainees, $35(85.4 \%)$ participants answered that they had a trainee policy, while $6(14.6 \%)$ answered that they did not. Most participants from companies that had a trainee policy $(n=31,88.6 \%)$ were familiar with the policy, but a considerable number $(n=4,11.4 \%)$ were unaware of the policy. Regarding orientation training for cadets, most companies $(n=37,90.2 \%)$ provided orientation training before onboard training, but four $(9.8 \%)$ did not. Regarding the purpose of the onboard training, $35(85.4 \%)$ participants said that the purpose was experience in the shipping field, $3(7.3 \%)$ said extension of schoolwork, 1 (2.4\%) said cultivation of social abilities, $1(2.4 \%)$ said the provision of extra manpower to help onboard seafarers, and 1 said another purpose (2.4\%).

Table 9 describes the company's views on the cadets. While most participants defined cadets as candidate officers $(n=20,48.8 \%)$ and students $(n=17,41.5 \%)$, two participants defined them as crew and temporary workers, respectively.

Table 9. Company's views on cadets.

\begin{tabular}{cccc}
\hline Definition of Cadets & $\boldsymbol{n}(\mathbf{\%})$ & Company's Expectation of Cadets & $\boldsymbol{n}(\mathbf{\%})$ \\
\hline A candidate officer & $20(48.8)$ & Eager to learn & $17(41.5)$ \\
A student & $17(41.5)$ & Hardworking & $1(2.4)$ \\
A crew member & $1(2.4)$ & Take responsibility for their job & $9(22)$ \\
A temporary worker & $1(2.4)$ & Sufficient knowledge of their area & $8(19.5)$ \\
Other & $2(4.9)$ & Ability to get along with others & $3(7.3)$ \\
& & Other & $3(7.3)$ \\
\hline
\end{tabular}

Regarding the company's expectations of cadets, the number of participants answering with being eager to learn, taking responsibility for their job, having sufficient knowledge of their area, ability to get along with others, being hardworking, and others accounted for $17(41.5 \%), 9(22.0 \%), 8(19.5 \%), 3(7.3 \%), 1(2.4 \%)$, and $3(7.3 \%)$, respectively. Other expectations included linking onboard training to employment and having a sense of community and safety.

Table 10 shows the company's views on onboard training. According to the data obtained from the questionnaire, safety issues and relationship problems between cadets and crew were the most difficult parts of cadet management. In addition, strengthening job-related and safety education were considered to be the most important factors for effective onboard training.

Table 10. Company's views on onboard training.

\begin{tabular}{|c|c|c|c|}
\hline $\begin{array}{l}\text { Difficulty of Cadet } \\
\text { Management }\end{array}$ & $n(\%)$ & $\begin{array}{c}\text { Important Factors for Effective } \\
\text { Onboard Training }\end{array}$ & $n(\%)$ \\
\hline $\begin{array}{l}\text { Adjustment of the period of } \\
\text { boarding }\end{array}$ & $2(4.9)$ & Strengthening job-related education & $21(51.2)$ \\
\hline Costs for onboard training & $4(9.8)$ & Strengthening safety education & $7(17.1)$ \\
\hline Safety issues & $22(53.7)$ & $\begin{array}{l}\text { Expanding training on } \\
\text { university/institute training ships }\end{array}$ & $3(7.3)$ \\
\hline $\begin{array}{l}\text { Relationship problems } \\
\text { between cadets and crew }\end{array}$ & 8 (19.5) & $\begin{array}{c}\text { Expansion of onboard } \\
\text { training period }\end{array}$ & $1(2.4)$ \\
\hline \multirow[t]{3}{*}{ Other } & $5(12.2)$ & $\begin{array}{l}\text { Government level support for } \\
\text { onboard training costs }\end{array}$ & $2(4.9)$ \\
\hline & & $\begin{array}{c}\text { Strengthening } \\
\text { leadership/seamanship training }\end{array}$ & $4(9.8)$ \\
\hline & & $\begin{array}{l}\text { Helping to form good human } \\
\text { relationships with crew }\end{array}$ & $3(7.3)$ \\
\hline
\end{tabular}




\section{Discussion}

Cadets should perform onboard training to meet the requirements set by the STCW for certification as officers, and onboard training should be carried out in a safe manner. However, accidents in which cadets are killed or injured during training continue to occur, depending on the inherent risks of ship sites, such as heavy-duty work, hot working conditions, and severe weather conditions. In response, through survey analysis, we found that there were differences in the onboard training environment among Korean maritime cadets and in the views about cadets and onboard training among the shipping companies' employees.

The key findings are discussed, and recommendations are made in four areas: living environment, personal safety, human rights, and views on cadets and onboard training.

\subsection{Living Environment}

Cadets should acquire the knowledge and competency required by the STCW through onboard training to become maritime officers. As shown in Table 3, however, 93 cadets did not have an internet connection, and 8 cadets did not even have a desk and chair. These points are similar to the findings by Yildız [7] that many deck cadets were not provided with individual cabins and amenities including toilets, refrigerators, televisions, and internet connections during their onboard training. As reported by Sampson and Tang, most seafarers mind sharing a cabin with others, and this could affect cadets' satisfaction with onboard training [20]. Academic achievement is affected by various factors, and learning facilities are one of these factors [21]. A lack of equipment such as desks and chairs can make it difficult to study, and the absence of an internet connection can limit access to information.

The backwardness of the equipment and availability of convenience facilities on the ship may affect the adaptability and safety of the cadets on board. Furthermore, providing facilities for various activities and personal convenience can help to improve the mental health of cadets [19]. Therefore, it is necessary for the government to evaluate whether the ship's environment is suitable for training and, if so, to ensure that the cadets board the ship for training purposes only.

\subsection{Personal Safety}

Cadets are vulnerable to the risks onboard ships, as they have no ship experience. In a close look at the reasons for disembarkation, the reasons were end of training $(n=220$, $77.5 \%)$, due to disease or accidents $(n=23,8.1 \%)$, company request $(n=22,7.7 \%)$, aborting the training according to individual opinions $(n=6,2.1 \%)$, and others $(n=13,4.6 \%)$. Most of the cadets disembarked because the training period was over, but a significant number stopped onboard training due to disease or accidents. In addition, regarding the average working hours per day, only $21 \%$ of the cadets worked for less than $8 \mathrm{~h}$ per day, while others worked for more than that. Fatigue is an issue in the maritime industry [22,23]. Both physical and mental fatigue can affect alertness and concentration [22], and can impact safety at work and individual ill health [24]. Most cadets worked for more than $9 \mathrm{~h}$ per day, which could affect them physically and mentally. It is difficult to conclude that longer working hours affect the rate of disembarkation of cadets by disease or accidents due to the small number of survey cases; however, it is necessary to manage the cadets' working hours, given that fatigue can cause accidents. Since the fatigue issue is related to various factors, not only shipping company-level efforts, but also government-level efforts are needed to solve it [25].

PPE is required during onboard training to minimize exposure to hazards on a ship. However, a significant number of cadets did not receive PPE (Figure 1), and some cadets did not receive a safety orientation before boarding. PPE and safety briefings need to be provided by the company because cadets are more likely to be exposed to the risk of accidents due to their lack of onsite experience. The Korean government enacted guidelines for the operation of practical training aboard ships for marine officer trainees in August 
2020 [26] (hereinafter referred to as onboard training guidelines), which provided necessary measures concerning onboard training. Shipowners should conduct onboard training according to the onboard training standard agreement pursuant of Article 21-2 of the Ship Personnel Act, and should allow an adaptation period during which simple observation is conducted for two weeks to enhance the ship adaptation of cadets. Furthermore, the shipowner should provide the cadets with meals, training materials, boiler suits, personal tools, PPE, and other items necessary for onboard training free of charge, and the onboard training time should not exceed $8 \mathrm{~h}$ per day or $40 \mathrm{~h}$ per week.

The newly enacted guidelines are thought to be a solution to the problem of personal safety identified through the survey. However, because creating a system in itself does not guarantee that all the related problems will be solved, the government needs to constantly monitor whether the system is well maintained in the field.

\subsection{Human Rights}

As noted by Zhao et al. [9] and Stannard et al. [17], sexual harassment is an issue onboard ships. A significant number of cadets experienced sexual harassment during their onboard training. It is noteworthy that not only female cadets but also male cadets experienced sexual harassment, and most perpetrators were officers who were in a position to evaluate their cadets (Table 5). Cadets responded passively when they were sexually harassed, by only talking to their friends or tolerating the harassment. Cadets must complete onboard training to obtain a seafarer's license and worry about getting a job after graduation. Therefore, they are reluctant to respond to unfair acts onboard ships because of the fear of disadvantage in future employment.

Onboard training guidelines require shipowners to regularly check the occurrence of violations of working hours and rest times, sexual harassment, assault, and verbal abuse during onboard training through a dedicated person. However, it is difficult to immediately report unfair acts on the ship to the dedicated person, as many cadets are onboard a ship with no internet connection (Table 3). In addition, it is questionable how actively the cadets will report unfair acts due to concerns about obtaining a job in the future.

Maritime cadets are future seafarers, who are key assets of shipping companies and related industries. For the sustainable growth of maritime industries, it is important to encourage cadets to continue their careers by giving them a positive perception of boarding a ship.

Therefore, it is necessary for shipowners to strengthen the preventive education of the ship's crew on assaults, verbal abuse, overuse of power, and sexual harassment on ships with cadets onboard, and the government must regularly monitor the status of preventive education and the onboard training environment. In addition, it is also necessary to establish a system to prevent cadets from being assigned to ships where those problems repeat.

\subsection{Views on Cadets and Onboard Training}

A cadet is a student who is not assigned the duties of a seafarer, according to Korean regulations, and is practicing onboard to become a seafarer [6]. Due to the small amount of data, it is difficult to ascertain the percentage of shipping companies in South Korea that consider cadets to be crew members or temporary workers. However, the data shows that cadets are recognized not only as students, but also as workers in the field. This recognition needs to be improved because it may lead to problems related to a focus on assisting the ship's work, rather than providing the cadets with systematic training in accordance with the on-site training plan.

Although the shipping company employees stated that safety issues are the most difficult part of managing cadets (Table 10), many cadets are not even given the most basic PPE (Figure 1). This shows that there is a limit to the shipping companies' autonomous efforts to improve the practical environment. Therefore, active monitoring at the government level 
is important to ensure that the recently enacted onboard training guidelines are followed at the site.

\section{Conclusions}

This study investigated the specific onboard training environment and the companies' views of onboard training and cadets through a survey analysis. Furthermore, improvement methods in four areas: living environment, personal safety, human rights, and views on cadets and onboard training were considered.

Based on the findings, the major recommendations are as follows:

(1) Evaluate whether the ship's environment is suitable for training, and only allow cadets to train on the ship if the environment is suitable.

(2) Constantly monitor whether the onboard training guidelines are actually well maintained in the field.

(3) Strengthen the preventive education of the crew on ships where cadets are present regarding assault, verbal abuse, overuse of power, and sexual harassment.

(4) Increase efforts continuously not only to physically improve the onboard training environment but to systematically manage cadets as students.

The problems identified in this research can have a direct impact on the safety of cadets, and can also result in negative perceptions about becoming a seafarer in the future. However, the problems identified in this study should not be generalized to all shipping companies without restriction. The data analyzed emanated from 284 cadets from maritime universities and 41 shipping company employees in South Korea. Future studies should increase the amount of collected data and monitor the implementation status of the new onboard training guidelines to improve the onboard training environment and the human rights of cadets.

Author Contributions: Conceptualization, J.L. and S.D.; methodology, J.L., S.D., and C.L.; software, J.L. and I.P.; validation, S.D. and C.L.; formal analysis, J.L.; investigation, J.L. and C.L.; resources, J.L. and S.D.; data curation, J.L. and I.P.; writing-original draft preparation, J.L.; writing-review and editing, S.D., I.P., M.J., and C.L.; visualization, J.L.; supervision, C.L.; project administration, C.L.; funding acquisition, M.J. All authors have read and agreed to the published version of the manuscript.

Funding: This research was funded by the Ministry of Education of the Republic of Korea and the National Research Foundation of Korea (NRF-2018S1A6A3A01081098).

Institutional Review Board Statement: The study was conducted in accordance with the guidelines for securing research ethics and the Article 33 (Protection of Secrets) of the Statistics Act in South Korea.

Informed Consent Statement: Informed consent was obtained from all subjects involved in the study.

Data Availability Statement: Not applicable.

Conflicts of Interest: The authors declare no conflict of interest. The funders had no role in the design of the study; in the collection, analyses, or interpretation of data; in the writing of the manuscript, or in the decision to publish the results.

\section{References}

1. UNCTAD. Review of Maritime Transport 2019. Available online: https://www.un-ilibrary.org/content/books/9789210043021 (accessed on 3 November 2020). [CrossRef]

2. Roberts, S.E.; Nielsen, D.; Kotłowski, A.; Jaremin, B. Fatal accidents and injuries among merchant seafarers worldwide. Occup. Med. (Chic. Ill.) 2014, 64, 259-266. [CrossRef] [PubMed]

3. Saunders, R. Assessment of professional development for teachers in the vocational education and training sector: An examination of the Concerns Based Adoption Model. Aust. J. Educ. 2012, 56, 182-204. [CrossRef]

4. Kim, B.-G.; Kim, H.-R.; Lim, M.-H. Method on the effective onboard training and guidance for apprentice engineer officers in the training ship-The case of Mokpo National Maritime University. J. Korean Soc. Mar. Environ. Saf. 2012, 18, 557-562. [CrossRef]

5. Sin, H.S.; Im, M.H.; Lee, C.H. A basic study on the stress of on-board training for cadet in shipping company. J. Fishries Mar. Sci. Educ. 2018, 30, 2231-2240. [CrossRef] 
6. Doo, H.W.; Jeon, Y.W.; Lim, C.H.; Jin, H.H. Study on improvements in management regime and legal statute of cadet. Marit. Law Rev. 2018, 30, 229-254. [CrossRef]

7. Yıldız, S.; Ugurlu, Ö.; Yüksekyıldız, E. Occupational issues and expectations of Turkish deck cadets. Trans. Nav. Int. J. Mar. Navig. Saf. Sea Transp. 2016, 10, 403-408. [CrossRef]

8. Lee, S.-I.; Yoo, J.-H.; Choi, J.-H. Constitutional legitimacy of the maritime cadet training system. J. Korean Soc. Mar. Environ. Saf. 2016, 22, 430-443. [CrossRef]

9. Zhao, M.; Zhao, L.; Zhang, P.; Wu, J.; Pike, K.; Broadhurst, E. Chinese women seafarers: A case study of the women cadets in Shanghai. Mar. Policy 2017, 83, 40-47. [CrossRef]

10. Status of National Port Volume Processing. Available online: http://www.index.go.kr/potal/main/EachDtlPageDetail.do?idx_ $c d=1265$ (accessed on 16 November 2019).

11. Seafarer Employment Status. Available online: http:/ / kosis.kr/search/search.do (accessed on 22 November 2019).

12. McLaughlin, H. Seafarers in the spotlight. Marit. Policy Manag. 2015, 42, 95-96. [CrossRef]

13. Explanatory Data. Available online: https:/ / www.mof.go.kr/article/view.do? menuKey=972\&boardKey=11\&articleKey=30364 (accessed on 31 January 2021).

14. Sevilla, G.S.; Arceno, R.A. Structured shipboard training program and performance of maritime cadets. Int. J. Engl. Lit. Soc. Sci. 2017, 2, 90-110. [CrossRef]

15. Sin, H.S.; Im, M.H. A basic study on the satisfaction of on-board training for cadets in shipping company. J. Fish. Mar. Sci. Educ. 2015, 27, 441-451. [CrossRef]

16. Thomas, M.A. Sexual harassment in a residential occupation: The experiences of women seafarers. Health Educ. J. 2006, 65, 170-179. [CrossRef]

17. Stannard, S.; Vaughan, C.; Swift, O.; Robinson, G.; Altaf, S.A.; McGarry, A. Women seafarers' health and welfare survey. Int. Marit. Health 2015, 66, 123-138. [CrossRef]

18. Mellbye, A.; Carter, T. Seafarers' depression and suicide. Int. Marit. Health 2017, 68, 108-114. [CrossRef]

19. Sampson, H.; Ellis, N. Seafarer's Mental Health and Wellbeing; IOSH: Wigston, UK, 2019.

20. Sampson, H.; Tang, L. Strange things happen at sea: Training and new technology in a multi-billion global industry. J. Educ. Work. 2016, 29, 980-994. [CrossRef]

21. Muola, J.M. A study of the relationship between academic achievement motivation and home environment among standard eight pupils. Educ. Res. Rev. 2010, 5, 213-217. [CrossRef]

22. Akhtar, M.J.; Utne, I.B. Human fatigue's effect on the risk of maritime groundings-A Bayesian Network modeling approach. Saf. Sci. 2014, 62, 427-440. [CrossRef]

23. Jepsen, J.R.; Zhao, Z.; van Leeuwen, W.M.A. Seafarer fatigue: A review of risk factors, consequences for seafarers' health and safety and options for mitigation. Int. Marit. Health 2015, 66, 106-117. [CrossRef]

24. Wadsworth, E.J.K.; Allen, P.H.; McNamara, R.L.; Smith, A.P. Fatigue and health in a seafaring population. Occup. Med. (Chic. Ill.) 2008, 58, 198-204. [CrossRef] [PubMed]

25. Lützhöft, M.; Grech, M.R.; Porathe, T. Information environment, fatigue, and culture in the maritime domain. Rev. Hum. Factors Ergon. 2011, 7, 280-322. [CrossRef]

26. Operation Guidelines for Onboard Training. Available online: https://www.law.go.kr/admRulSc.do?menuId=5\%5C\& subMenuId $=41 \% 5$ C\&tabMenuId $=183 \% 5$ C\&query $=\% E C \% 8 \mathrm{~A} \% \mathrm{~B} 9 \% \mathrm{EC} \% 84 \% \mathrm{~A} 0 \% \mathrm{EC} \% 8 \mathrm{~B} \% \mathrm{~A} 4 \% \mathrm{EC} \% 8 \mathrm{~A} \% \mathrm{~B} 5 \% 5 \mathrm{C}$ (accessed on 30 January 2021). 